NOTE

\title{
Pelagic larval duration and geographic distribution of tropical eastern Pacific snappers (Pisces: Lutjanidae)
}

\author{
Fernando A. Zapata*, Pilar A. Herrón** \\ Departamento de Biología, Universidad del Valle, Apartado Aéreo 25360, Cali, Colombia
}

\begin{abstract}
To test the hypothesis that pelagic larval duration (PLD) plays a role in the longitudinal dispersal of reef fishes, we examined the relationship between PLD and occupancy of oceanic islands among tropical eastern Pacific (TEP) snappers (Lutjanidae). We estimated PLD from analysis of the otolith microstructure of juveniles collected at 2 localities from the Pacific coast of Colombia. Otoliths had a distinct 1increment settlement transition, along which increment width gradually decreased in 1 species examined (Lutjanus guttatus). PLD estimated from lapilli was relatively short (21.8 to $24.4 \mathrm{~d}$ ) and invariant (3.1 to $9.6 \%$ coefficients of variation [CV]) in $L$. argentiventris, L. guttatus, L. novemfasciatus, and Hoplopagrus guntheri, but was relatively long in $L$. viridis $(37.9 \mathrm{~d}, \mathrm{CV}=8.6 \%)$. Mean PLD was not correlated with the largest distance between any 2 localities occupied but was positively correlated with number of oceanic islands occupied. Consideration of the geographic isolation of each island improved the strength of the latter relationship. However, these patterns were largely due to $L$. viridis, which was present in all oceanic islands, including Clipperton Atoll, the most isolated island in the TEP. This study suggests that the longitudinal component of species' ranges (measured by occupancy of reefs around oceanic islands) reflect dispersal abilities, yet overall range size is independent of PLD because other factors determine other components of geographic range.
\end{abstract}

KEY WORDS: Early life history - Geographic range size • Lutjanidae · Otolith microstructure · Pelagic larval duration . Reef fishes

Resale or republication not permitted

without written consent of the publisher

Most tropical reef fishes have a life cycle that includes planktonic larvae and benthic adults (Thresher 1984, Leis 1991). Larval transport by currents is the most likely mechanism of dispersal because adults are relatively sedentary and the distribution of reef habitats is patchy (Sale 1978). Consequently, the

Present addresses:

* Department of Zoology and Entomology, University of Pretoria, Pretoria 0002, South Africa.

E-mail: fazapata@zoology.up.ac.za

${ }^{* *}$ Department of Marine Science and Coastal Management, University of Newcastle upon Tyne, Newcastle upon Tyne NE1 7RU, United Kingdom hypothesis that dispersal ability and extent of geographic distribution are functions of pelagic larval duration (PLD) has received considerable attention (Victor 1991). Although intuitively appealing, this idea has only weak empirical support. Among Indo-Pacific reef fishes, Brothers \& Thresher (1985) reported a threshold of approximately $45 \mathrm{~d}$ in PLD, above which species tended to be widespread. Widely distributed Indo-Pacific species, such as Pacific Plate endemics (Springer 1982) and those that range into isolated areas like Hawaii and the eastern Pacific, have longer PLDs than more geographically restricted species (Brothers \& Thresher 1985, Victor 1986a, Thresher et al. 1989). Pomacentrid genera with restricted distributions tend to have shorter PLDs (Wellington \& Victor 1989, Cowen \& Sponaugle 1997), but the opposite tends to be true for labrids (Victor 1986a, Cowen \& Sponaugle 1997). At the species level, there is no evidence of a correlation between PLD and range size among IndoPacific pomacanthids (Thresher \& Brothers 1985) and pomacentrids (Thresher et al. 1989, Wellington \& Victor 1989), or among tropical eastern Pacific (TEP) labrids and pomacentrids (Victor \& Wellington 2000). Furthermore, recent findings regarding the strong swimming abilities of reef fish larvae (Leis \& CarsonEwart 1997, Stobutzki \& Bellwood 1997, Stobutzki 1998, Fisher et al. 2000) and local larval retention in some coral reef fish populations (Jones et al. 1999, Swearer et al. 1999, Cowen et al. 2000) suggest that passive larval transport by currents plays a minor role in determining the geographic distribution of reef fishes.

The TEP is a region with suitable reef-fish habitat along the American continental coast and in a few oceanic island groups (Allen \& Robertson 1994, Glynn \& Ault 2000). Geographic ranges of some species in this region have strong latitudinal and longitudinal components. Latitudinal limits of distribution are likely a function of thermal tolerances because this region is characterized by sharp temperature gradients both to 
the north and to the south (Briggs 1974, Brusca \& Wallerstein 1979). However, PLD may play a key role in the longitudinal dispersal of species. If so, the presence of species around oceanic islands at different distances from source populations of reef fishes should be related to PLD. In this study, we used otolith microstructure of TEP snappers (Lutjanidae) to estimate PLD and then examined the relationship between PLD and extent of geographic range on oceanic islands.

Materials and methods. Pelagic larval duration: We estimated PLD by examination and analysis of the microstructure of juvenile fish otoliths, which has become a standard methodology for the study of fish early life history (Victor 1991, Stevenson \& Campana 1992, Secor et al. 1995). Using a combination of techniques, we collected juvenile snappers from coral and rocky reef areas of Gorgona Island $\left(2^{\circ} 56^{\prime} \mathrm{N}, 78^{\circ} 11^{\prime} \mathrm{W}\right)$ between May 1997 and November 1999, and at Ensenada de Utría $\left(6^{\circ} 04^{\prime} \mathrm{N}, 77^{\circ} 25^{\prime} \mathrm{W}\right)$ in September 1998. At Gorgona, individuals were also captured on clusters of coral rubble, similar to those previously used by Sweatman (1983). These were placed on sandy substrates far from reef areas to attract new settlers. After collection, specimens were preserved in 95\% ethyl alcohol and transported to the laboratory.

We dissected the fish, and extracted, prepared and polished the otoliths following the methods described by Secor et al. (1992) with modifications by Wilson \& McCormick (1997, 1999) and Wilson (2000). Otolith microstructure was examined using a light microscope (150 to $1200 \times$ magnification) connected through a digital video camera to a computer. Image analysis software (Q-Win, Leica) facilitated the observation and measurement of otolith increments, although increment counts were made visually while the otolith image was displayed on the computer screen and the focus could be adjusted to facilitate counting. After initial comparisons we found that both sagittae and lapilli yielded similar results, although lapilli were easier and less time consuming to prepare and interpret than sagittae. We therefore used lapilli for the estimation of PLD in all species.

Otoliths from 114 of the 123 individuals collected were sufficiently clear for interpretation and analysis. PLD for individual fish was estimated from 3 replicate counts of the growth increments present from the nucleus either outward to the edge of the otolith or to the settlement mark associated with the transition from a planktonic to a benthic habit (Wilson \& McCormick 1997, 1999). Each otolith reading was assigned a score representing the degree of perceived confidence in its interpretation following the weighting method described by Campana \& Jones (1992). Only 1 otolith had replicate readings that varied by $>10 \%$, resulting in its exclusion from further analysis.
Increment deposition was assumed to begin at the time of hatching (Radtke \& Dean 1982) because incubation times of lutjanids are relatively short (Thresher 1984, Leis 1987, Doi et al. 1994). Preliminary validation experiments with tetracycline marking indicated that increments of sagittae are deposited at an average rate of 1.0 increment $\mathrm{d}^{-1}$ in Hoplopagrus guntheri and 1.2 increments $\mathrm{d}^{-1}$ in Lutjanus guttatus (Bárcenas 1999). The daily formation of otolith increments has also been demonstrated for other lutjanids (Ralston \& Miyamoto 1983, Radtke 1987). Although subdaily increments were evident, generally in the zone of the greatest increment width (Fig. 1), these were easily discriminated following the recommendations of Victor (1986a) and Campana (1992).

Widths of growth increments were measured along a profile in 6 specimens of Lutjanus guttatus and were plotted using the 'transition-centered' method (Wilson $\&$ McCormick 1997) to examine the pattern of change in increment width around the transition zone (see also Victor 1986b, Fowler 1989, Cowen 1991). Statistical comparisons of increment widths along the profile, and before and after the settlement mark were made using a 1-factor repeated measures ANOVA. To examine interspecific differences in PLD, we used a 1-way ANOVA to compare mean individual estimates of PLD among species and a Tukey multiple comparison test to determine which species differed from the others (Zar 1996).

Geographic distribution: Geographic distribution information obtained from different sources (primarily López \& Bussing 1982, Eschmeyer et al. 1983, Rubio et al. 1987, 1992, Goodson 1988, Humann 1993, Allen \& Robertson 1994, Allen 1995, Grove \& Lavenberg 1997, Chirichigno \& Vélez 1998, Thomson et al. 2000) was used to document species occupancy in previously defined continental biogeographic provinces (Brusca \& Wallerstein 1979, Hastings 2000) and oceanic islands of the TEP. Three measures of range size were used: (1) the greatest distance between any 2 occupied localities; (2) the number of oceanic islands occupied; and (3) the sum of the distances between each island occupied and its nearest land mass. The latter 2 measures were used to examine patterns of island occupancy in relation to PLD and differ in the explicit consideration of geographic isolation.

Results and discussion. Otolith internal microstructure and PLD: The microstructure of the otoliths was similar in all 5 species. The first increments around the nucleus were very narrow and progressively increased in width with distance from the nucleus (Fig. 1). In otoliths of older juveniles there was an evident transition in the optical contrast and resolution of the increments and a slight decrease in their width. A conspicuously dark increment usually marked the begin- 
ning of such a transition, and this was considered to be the settlement mark (Fig. 1). Although occasionally other increments were also conspicuously dark, these were never consistently so around the entire circumference of the otolith. PLD estimates for Hoplopagrus guntheri and Lutjanus guttatus did not differ significantly between individuals with or without the presumed settlement transition (Table 1). PLD in individuals of $L$. argentiventris without a transition was on average $2 \mathrm{~d}$ longer than in other individuals, but the difference was not statistically significant (Student's $t$-test, $p>0.05$ ). This suggests that the transition mark coincides with the time of settlement in these 3 species. In contrast, mean PLD in individuals of $L$. viridis without a transition was significantly greater (4 d) than in individuals with the presumed settlement mark (Table 1). Using unweighted instead of weighted means did not change this result (Student's $t$-test, $\mathrm{p}=0.008$ ). However, individuals of $L$. viridis without a transition were collected between July and August 1998 in the coral rubble clusters used to attract new settlers, while juveniles with a transition were collected between August and November 1997 at Gorgona's 2 main coral reefs. Because the 2 cohorts were separated in time by about $1 \mathrm{yr}$, the observed difference in PLD may have resulted from exposure to different environmental conditions, such as the strong El Niño warming event of 1997-98.

Increment profiles of Lutjanus guttatus showed a consistent, though not abrupt, decrease in increment width of lapilli after the presumed settlement mark (Fig. 2). There was significant variation in increment width across the profile (repeated measures ANOVA, $F_{15,75}=4.36, \mathrm{p}<0.0001$, considering only increments -10 to +6 for which replication was complete, $\mathrm{n}=6$ ) with increment widths after the settlement mark being significantly narrower than those before it (planned comparison $F_{1,5}=150.6, \mathrm{p}<0.0001$ ). The same result was obtained after excluding all replicate values corresponding to increment -9 , which exhibited the greatest mean width. Considering all data (increments -10 to +10$)$, increment widths before the mark (mean \pm SE: $13.6 \pm 0.38 \mu \mathrm{m}$ ) were greater than after the mark $(10.1 \pm 0.37 \mu \mathrm{m})$.

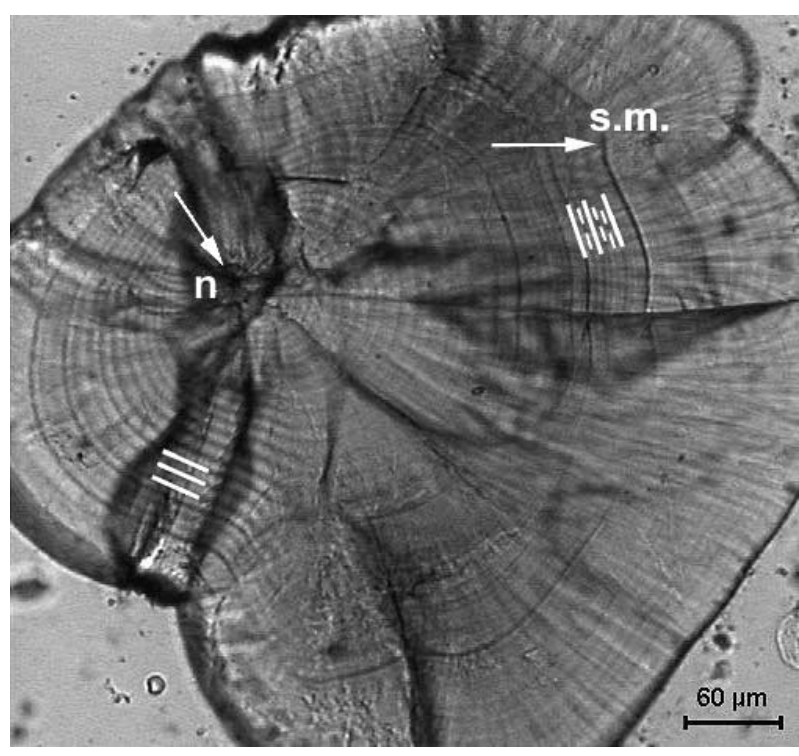

Fig. 1. Lutjanus guttatus. Microstructure of a lapillus after polishing procedure. Arrows indicate the position of the nucleus (n) and the settlement mark (s.m.). Solid lines indicate daily increments while finer, dashed lines indicate subdaily increments. Note the narrowing of increments after the settlement mark

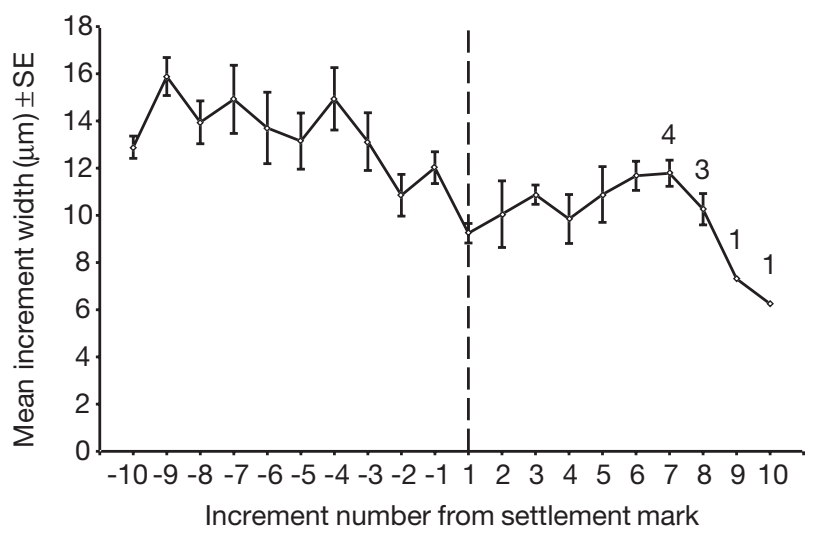

Fig. 2. Lutjanus guttatus. Increment width profile using the 'transition-centered' method (Wilson \& McCormick 1997). Dashed line indicates the location of the settlement transition. $\mathrm{n}=6$ at all points except where indicated

Table 1. Mean pelagic larval durations $( \pm$ SE) of 4 Colombian Pacific lutjanids in individuals with and without a presumed settlement mark (SM) in their otoliths. Most individuals without a SM were collected on isolated clusters of coral rubble and appeared to be newly settled because they were smaller, translucent or lacked the coloration typical of older juveniles

\begin{tabular}{|c|c|c|c|c|c|}
\hline \multirow[t]{2}{*}{ Species } & \multicolumn{2}{|c|}{ With SM } & \multicolumn{2}{|c|}{ Without SM } & \multirow{2}{*}{$\begin{array}{c}t \text {-test } \\
\mathrm{p} \text {-value }\end{array}$} \\
\hline & Mean \pm SE & $\mathrm{n}$ & Mean \pm SE & $\mathrm{n}$ & \\
\hline Hoplopagrus guntheri & $21.9 \pm 0.44$ & 10 & $21.0 \pm 0.33$ & 9 & 0.326 \\
\hline Lutjanus argentiventris & $21.3 \pm 0.30$ & 11 & $23.3 \pm 0.46$ & 4 & 0.053 \\
\hline L. guttatus & $24.1 \pm 0.57$ & 26 & $24.7 \pm 0.26$ & 18 & 0.449 \\
\hline L. viridis & $36.2 \pm 0.42$ & 11 & $40.4 \pm 0.42$ & 8 & 0.002 \\
\hline
\end{tabular}


Table 2. Estimates of mean pelagic larval duration (PLD) $( \pm \mathrm{SE})$ in 5 species of Lutjanidae from the Colombian Pacific Ocean based on the number of increments observed in lapilli. Means indicated by the same superscript letter did not differ significantly at $\alpha=0.05$ based on Tukey's test for unequal sample sizes involving samples from Gorgona Island only. CV\%: coefficient of variation

\begin{tabular}{|c|c|c|c|c|c|}
\hline Species & Location & $\mathrm{PLD} \pm \mathrm{SE}(\mathrm{d})$ & Range & $\mathrm{CV} \%$ & $\mathrm{n}$ \\
\hline Hoplopagrus guntheri & Gorgona Island & $21.5 \pm 0.40^{\mathrm{a}}$ & $18-24$ & 8.56 & 19 \\
\hline \multirow[t]{2}{*}{ Lutjanus argentiventris } & Gorgona Island & $21.9 \pm 0.39^{\mathrm{a}}$ & $19-27$ & 8.28 & 15 \\
\hline & Ensenada de Utría & $23.7 \pm 0.18$ & $23-25$ & 3.67 & 3 \\
\hline \multirow[t]{2}{*}{ L. guttatus } & Gorgona Island & $24.4 \pm 0.47^{\mathrm{b}}$ & $20-32$ & 9.63 & 45 \\
\hline & Ensenada de Utría & $24.1 \pm 0.19$ & $23-25$ & 3.91 & 2 \\
\hline \multirow[t]{2}{*}{ L. novemfasciatus } & Gorgona Island & $20.6 \pm 0.26^{\mathrm{a}}$ & $20-23$ & 6.00 & 5 \\
\hline & Ensenada de Utría & $22.9 \pm 0.15$ & $22-24$ & 3.14 & 6 \\
\hline L. viridis & Gorgona Island & $37.9 \pm 0.53^{c}$ & $31-44$ & 8.60 & 19 \\
\hline
\end{tabular}

In the 5 lutjanids examined, the frequency distribution of PLDs did not differ from normal. Lutjanus viridis showed both the greatest mean and range in PLD followed by L. guttatus (Table 2). Mean PLD in these 2 species was significantly longer than in the other 3 species (ANOVA based on specimens from Gorgona Island, $F=136.10, \mathrm{p}<0.001$, Table 2), which in turn did not differ significantly in PLD. L. guttatus showed the highest intraspecific variability, although its variance in PLD only differed significantly from that of L. novemfasciatus from Ensenada de Utría $(F=10.78, \mathrm{p}<0.02)$. In general, coefficients of variation in PLD were relatively small, varying between 3.1 and 9.6\% (Table 2).

TEP lutjanids had PLDs within the range of values reported for other lutjanids. Known PLDs are $25 \mathrm{~d}$ in newly settled, unidentified Indo-Pacific lutjanids (Brothers et al. 1983), 40 d in Lutjanus sebae (Brothers \& Thresher 1985), $26.1 \mathrm{~d}$ in L. fulvifflamma and $62 \mathrm{~d}$ in L. gibbus (Wilson \& McCormick 1999). Richards \& Saksena (1980) found a larval duration of $4 \mathrm{wk}$ for the western Atlantic L. griseus raised in captivity. However, our findings and most other estimates indicate that tropical lutjanids have relatively short PLDs; most values are within the lower third of the range reported for coral reef fishes ( 7 to $150 \mathrm{~d}$; Cowen \& Sponaugle 1997). Intraspecific variability in PLD of lutjanids appears to be low as well, but small sample sizes in most studies do not permit an adequate assessment of this trait. In TEP lutjanids, interspecific differences in PLD were greater among some congeners (e.g. L. viridis and L. guttatus vs other species of Lutjanus) than between at least 1 other genus (Hoplopagrus) and some species of Lutjanus, suggesting that PLD is not a phylogenetically conservative character within the family Lutjanidae.

PLD and geographic range: The 5 species studied here appear, at first, to have similar geographic distributions (Table 3 ) because they all inhabit rocky and coral reef habitats along the mainland coast throughout the TEP region. In fact, mean PLD was not corre-

Table 3. Pelagic larval duration (PLD) and geographic distribution of 5 lutjanids on continental biogeographic provinces and oceanic islands of the (primarily) tropical eastern Pacific Ocean. Continental biogeographic provinces are as follows: CAL, Californian (Point Conception, California to Punta Eugenio, Baja California Sur); COR, Cortezian (Bahia Magdalena and Gulf of California to Topolabampo, Sinaloa); MEX, Mexican (southwestern Mexico from Mazatlán, Sinaloa to Puerto Angel, Oaxaca); and PAN, Panamanian (Gulf of Fonseca, Honduras-Nicaragua border to Gulf of Guayaquil, Ecuador). Oceanic islands (and distance to nearest land) are as follows: MAL, Malpelo (362 km to Gorgona Island, Colombia); REV, Revillagigedo Islands (454 km to Cabo San Lucas); COC, Isla del Coco (501 km to Isla del Caño, Costa Rica); GAL, Galapagos Islands (750 km to Isla del Coco); and CLI, Clipperton Atoll (947 km to Revillagigedo Islands). Range size is the great circle distance between the 2 most distant localities. Minimum oceanic range is the sum of the distances between each island occupied and its nearest land

\begin{tabular}{|c|c|c|c|c|c|c|c|c|c|c|c|c|}
\hline \multirow[t]{2}{*}{ Species } & \multirow{2}{*}{$\begin{array}{l}\text { Mean } \\
\text { PLD } \\
\text { (d) }\end{array}$} & \multicolumn{4}{|c|}{ Continental province } & \multicolumn{5}{|c|}{ Oceanic Island } & \multirow{2}{*}{$\begin{array}{c}\text { Range } \\
\text { size } \\
(\mathrm{km})\end{array}$} & \multirow{2}{*}{$\begin{array}{l}\text { Minimum } \\
\text { oceanic } \\
\text { range }(\mathrm{km})\end{array}$} \\
\hline & & CAL & COR & MEX & PAN & MAL & REV & $\mathrm{COC}$ & GAL & CLI & & \\
\hline Hoplopagrus guntheri & 21.5 & & + & + & + & & & & + & & 5158 & 750 \\
\hline Lutjanus argentiventris & 22.2 & + & + & + & + & + & & + & + & & 5916 & 1613 \\
\hline L. guttatus & 24.4 & & + & + & + & + & & + & & & 5385 & 863 \\
\hline L. novemfasciatus & 21.8 & & + & + & + & + & & & + & & 5209 & 1112 \\
\hline L. viridis & 37.9 & & + & + & + & + & + & + & + & + & 4976 & 3014 \\
\hline
\end{tabular}


lated with the greatest distance between any 2 occupied localities $(\mathrm{r}=-0.522, \mathrm{p}=0.366)$. However, mean PLD was significantly and positively correlated with the number of oceanic islands occupied $(r=0.889, p=0.043$; Table 3). The correlation was greater when the degree of geographic isolation of the islands was taken into account by considering the sum of the distances between each oceanic island occupied and its nearest land mass $(r=0.911, p=0.032)$. Although suggestive, these results should be considered with caution due to the small number of species and oceanic islands considered. Lutjanus guttatus is not as widely distributed on oceanic islands as expected on the basis of its PLD, and the overall pattern is largely dependent upon the effect of only 1 species ( $L$. viridis), which had a PLD $14 \mathrm{~d}$ longer than that of the other 4 lutjanids. This suggests that the greater PLD of $L$. viridis has allowed it to colonize oceanic islands within the TEP that the others have not.

The presence of Lutjanus viridis at Clipperton Atoll may be of particular significance because this is a small, remote island and has the most isolated coral reefs within the TEP region ( $\sim 950 \mathrm{~km}$ from the Revillagigedo Islands; Robertson \& Allen 1996). Also, it is located at the westernmost limit of the TEP and a large proportion ( $55 \%$ ) of its shorefish fauna is transpacific rather than TEP endemic, probably due to the strong influence of eastbound currents coming from Oceania (Robertson \& Allen 1996). Based on differences in morphology and coloration, it is apparent that the nearest relatives of $L$. viridis are more likely to be species from the central and western Pacific than from the TEP or the Caribbean (G. R. Allen pers. comm.). Furthermore, most transpacific fishes have relatively long PLDs (Brothers \& Thresher 1985, Victor 1986a). Thus, an alternative explanation consistent with the widespread geographic distribution and prolonged PLD exhibited by $L$. viridis is that an ancestor successfully crossed the East Pacific Barrier and first colonized the oceanic islands, from which it spread to the rest of the TEP. Both explanations (i.e. colonization from the mainland or a trans-Pacific ancestry) suggest that a relatively long PLD may have enabled $L$. viridis to colonize distant oceanic islands. Overall, this study suggests that the longitudinal component of species' ranges, reflected by occupancy of oceanic islands, correlates with dispersal abilities, yet overall range size is independent of PLD because other factors determine other components of a species' range.

Acknowledgements. We thank C. E. Bárcenas, S. Lozano and C. Mora for help with field work. R. K. Cowen, S. Sponaugle and B. P. Steves introduced F.A.Z. to techniques for otolith studies and, along with T. and G. Grothues, provided generous hospitality and friendship. G. G. Wilson provided essential laboratory materials and helpful advice, and made available to us unpublished results from his research. D. R. Robertson pointed out to us the distinct geographic distribution of Lutjanus viridis. R. T. Kneib, D. T. Wilson, D. R. Robertson and 2 anonymous reviewers provided helpful comments on the manuscript. Research at Gorgona Island and Ensenada de Utría was permitted by the Special Administrative Unit of the System of National Natural Parks (UAESPNN), Colombian Ministry of the Environment. UAESPNN personnel, particularly C. Acevedo and G. Mayor, provided much on-site support. This research was funded by grant 1106-09-088-96 from COLCIENCIAS to F.A.Z. and is part of a BSc thesis submitted by P.A.H. to Universidad del Valle. The manuscript was completed while F.A.Z. was on leave at the Department of Zoology and Entomology, University of Pretoria. Support from S. L. Chown and C. H. Scholtz is gratefully acknowledged.

\section{LITERATURE CITED}

Allen GR (1995) Lutjanidae. In: Fischer W, Krupp F, Schneider W, Sommer C, Carpenter KE, Niem VH (eds) Guía FAO para la identificación de especies para los fines de la pesca. Pacífico centro-oriental, Vol III. Organización de las Naciones Unidas para la Agricultura y la Alimentación, Roma, p 1231-1244

Allen GR, Robertson DR (1994) Fishes of the tropical eastern Pacific. University of Hawaii Press, Honolulu, HI

Bárcenas CE (1999) Frecuencia de formación de incrementos en otolitos de peces juveniles de arrecifes coralinos del Pacífico colombiano. BSc thesis, Departamento de Biología, Universidad del Valle, Cali

Briggs JC (1974) Marine zoogeography. McGraw-Hill, New York

Brothers EB, Thresher RE (1985) Pelagic duration, dispersal and the distribution of Indo-Pacific coral reef fishes. In: Reaka ML (ed) The ecology of coral reefs. Symposia Series for Undersea Research. NOAA's Undersea Research Program, Vol 3, No 1. US Department of Commerce, Washington, DC, p 53-69

Brothers EB, Williams DMcB, Sale PF (1983) Length of larval life in twelve families of fishes at One Tree Lagoon, GBR, Australia. Mar Biol 76:319-324

Brusca RC, Wallerstein BR (1979) Zoogeographic pattern of idoteid isopods in the northeast Pacific, with a review of shallow water zoogeography of the area. Bull Biol Soc Wash 3:67-105

Campana SE (1992) Measurement and interpretation of the microstructure of fish otoliths. In: Stevenson DK, Campana SE (eds) Otolith microstructure examination and analysis. Can Spec Publ Fish Aquat Sci 117:59-71

Campana SE, Jones CM (1992) Analysis of otolith microstructure data. In: Stevenson DK, Campana SE (eds) Otolith microstructure examination and analysis. Can Spec Publ Fish Aquat Sci 117:73-100

Chirichigno N, Vélez J (1998) Clave para identificar los peces marinos del Perú. Instituto del Mar del Perú, Callao

Cowen RK (1991) Variation in the planktonic larval duration of the temperate wrasse Semicossyphus pulcher. Mar Ecol Prog Ser 69:9-15

Cowen RK, Sponaugle S (1997) Relationships between early life history traits and recruitment among coral reef fishes. In: Chambers RC, Trippel EA (eds) Early life history and recruitment in fish populations. Chapman \& Hall, London, p 423-448

Cowen RK, Lwiza KMM, Sponaugle S, Paris CB, Olson DB (2000) Connectivity of marine populations: open or closed? Science 287:857-859 
Doi M, Kohno H, Taki Y, Ohno A, Singhagraiwan T (1994) Morphological development of eggs, larvae and juveniles of the red snapper Lutjanus argentimaculatus (Pisces: Lutjanidae). J Tokyo Univ Fish Tokyo Suisandai Kempo 81:135-153

Eschmeyer WN, Herald ES, Hammann H (1983) A field guide to Pacific coast fishes of North America. Houghton Mifflin Company, Boston, MA

Fisher R, Bellwood DR, Job SD (2000) Development of swimming abilities in reef fish larvae. Mar Ecol Prog Ser 202:163-173

Fowler AJ (1989) Description, interpretation and use of the microstructure of otoliths from juvenile butterflyfishes (family Chaetodontidae). Mar Biol 102:167-181

Glynn PW, Ault JS (2000) A biogeographic analysis and review of the far eastern Pacific coral reef region. Coral Reefs 19:1-23

Goodson G (1988) Fishes of the Pacific coast. Stanford University Press, Stanford, CA

Grove JS, Lavenberg RJ (1997) The fishes of the Galápagos Islands. Stanford University Press, Stanford

Hastings PA (2000) Biogeography of the tropical eastern Pacific: distribution and phylogeny of chaenopsid fishes. Zool J Linn Soc 128:319-335

Humann P (1993) Reef fish identification: Galápagos. New World Publications, Jacksonville, FL

Jones GP, Milicich MJ, Emslie MJ, Lunow C (1999) Selfrecruitment in a coral reef fish population. Nature 402: 802-804

Leis JM (1987) Review of the early life history of tropical groupers and snappers. In: Polovina JJ, Ralston S (eds) Tropical snappers and groupers. Biology and fisheries management. Westview Press, Boulder, CO, p 189-237

Leis JM (1991) The pelagic stage of reef fishes: the larval biology of coral reef fishes. In: Sale PF (ed) The ecology of fishes on coral reefs. Academic Press, San Diego, CA, p 183-230

Leis JM, Carson-Ewart BM (1997) In situ swimming speeds of the late pelagic larvae of some Indo-Pacific coral-reef fishes. Mar Ecol Prog Ser 159:165-174

López MI, Bussing WA (1982) Lista provisional de los peces marinos de la costa Pacífica de Costa Rica. Rev Biol Trop 30:5-26

Radtke RL (1987) Age and growth information available from the otoliths of the Hawaiian snapper Pristipomoides filamentosus. Coral Reefs 6:19-25

Radtke RL, Dean JM (1982) Increment formation in the otoliths of embryos, larvae and juveniles of the mummichog, Fundulus heteroclitus. Fish Bull 80:201-215

Ralston S, Miyamoto GT (1983) Analyzing the width of daily otolith increments to age the Hawaiian snapper Pristipomoides filamentosus. Fish Bull 81:523-535

Richards WJ, Saksena VP (1980) Description of larvae and early juveniles of laboratory-reared gray snapper, Lutjanus griseus (Linnaeus) (Pisces, Lutjanidae). Bull Mar Sci 30: $515-521$

Robertson DR, Allen GR (1996) Zoogeography of the shorefish fauna of Clipperton Atoll. Coral Reefs 15:121-131

Rubio EA, Gutiérrez B, Franke R (1987) Peces de la Isla de Gorgona. Centro de Publicaciones, Facultad de Ciencias, Universidad del Valle, Cali

Rubio EA, Suárez A, Estupiñán F, Henao W, Vargas B (1992) Los recursos ictiológicos de la Isla de Malpelo (Colombia). I. Una revisión de su conocimiento y nuevos reportes para la ictiofauna de la isla. Comisión Colombiana de Oceanografía, VIII Seminario Nacional de Ciencias y Tecnologías del Mar y Congreso Centroamericano del

Editorial responsibility: Ronald Kneib (Contributing Editor), Sapelo Island, Georgia, USA
Caribe en Ciencias del Mar. Memorias II:642-658

Sale PF (1978) Reef fishes and other vertebrates: a comparison of social structures. In: Reese ES, Lighter FJ (eds) Contrasts in behavior. John Wiley \& Sons, New York, p 313-346

Secor DH, Dean JM, Laban EH (1992) Otolith removal and preparation for microstructural examination. In: Stevenson DK, Campana SE (eds) Otolith microstructure examination and analysis. Can Spec Publ Fish Aquat Sci 117:19-57

Secor DH, Dean JM, Campana SE (1995) Recent development in fish otolith research. University of South Carolina Press, Columbia, SC

Springer VG (1982) Pacific Plate biogeography, with special reference to shorefishes. Smithson Contrib Zool 367:1-182

Stevenson DK, Campana SE (1992) Otolith microstructure examination and analysis. Can Spec Publ Fish Aquat Sci Vol 117, Department of Fisheries and Oceans, Ottowa

Stobutzki IC (1998) Interspecific variation in sustained swimming ability of late pelagic stage reef fish from two families (Pomacentridae and Chaetodontidae). Coral Reefs 17:111-119

Stobutzki IC, Bellwood DR (1997) Sustained swimming abilities of the late pelagic stages of coral reef fishes. Mar Ecol Prog Ser 149:35-41

Swearer SE, Caselle JE, Lea DW, Warner RR (1999) Larval retention and recruitment in an island population of a coral-reef fish. Nature 402:799-802

Sweatman HPA (1983) Influence of conspecifics on choice of settlement sites by larvae of two pomacentrid fishes (Dacyllus aruanus and D. reticulatus) on coral reefs. Mar Biol 75:223-229

Thomson DA, Findley LT, Kerstitch AN (2000) Reef fishes of the Sea of Cortez. University of Texas Press, Austin, TX

Thresher RE (1984) Reproduction in reef fishes. TFH Publications, Neptune City, NJ

Thresher RE, Brothers EB (1985) Reproductive ecology and biogeography of Indo-West Pacific angelfishes (Pisces: Pomacanthidae). Evolution 39:878-887

Thresher RE, Colin PL, Bell LJ (1989) Planktonic duration, distribution and population structure of western and central Pacific damselfishes (Pomacentridae). Copeia 1989:420-434

Victor BC (1986a) Duration of the planktonic larval stage of one hundred species of Pacific and Atlantic wrasses (family Labridae). Mar Biol 90:317-326

Victor BC (1986b) Delayed metamorphosis with reduced larval growth in a coral reef fish (Thalassoma bifasciatum). Can J Fish Aquat Sci 43:1208-1213

Victor BC (1991) Settlement strategies and biogeography of reef fishes. In: Sale PF (ed) The ecology of fishes on coral reefs. Academic Press, San Diego, CA, p 231-260

Victor BC, Wellington GM (2000) Endemism and pelagic larval duration of reef fishes in the eastern Pacific Ocean. Mar Ecol Prog Ser 205:241-248

Wellington GM, Victor BC (1989) Planktonic larval duration of one hundred species of Pacific and Atlantic damselfishes (Pomacentridae). Mar Biol 101:557-567

Wilson DT, McCormick MI (1997) Spatial and temporal validation of settlement-marks in the otoliths of tropical reef fishes. Mar Ecol Prog Ser 153:259-271

Wilson DT, McCormick MI (1999) Microstructure of settlement-marks in the otoliths of tropical reef fishes. Mar Biol 134:29-41

Wilson GG (2000) Early post-settlement life history of Lethrinus species on the Great Barrier Reef: systematics, distribution and development. Doctoral thesis, James Cook University of North Queensland, Townsville

Zar JH (1996) Biostatistical analysis, 3rd edn. Prentice-Hall, Upper Saddle River, NJ

Submitted: July 29, 2000; Accepted: November 10, 2001

Proofs received from author(s): March 28, 2002 